The Sale of Edited Electoral Registers in Scotland:

Implications for Privacy, Data Protection and Citizenship

Charles Leleux and C William R Webster

This article has been accepted for publication in Scottish Affairs by Edinburgh

University Press. http://www.euppublishing.com/journal/scot 


\section{The Sale of Edited Electoral Registers in Scotland: Implications for Privacy, Data Protection and Citizenship}

\section{Charles Leleux and C William R Webster}

Charles Leleux is a Researcher with the Centre for Research into Information, Surveillance and Privacy (CRISP), within Stirling Management School at the University of Stirling. His research interests include: neighbourhood watch, workplace surveillance, and the growing trend by the state and public bodies of selling large datasets containing citizens' information. Charles Leleux, Stirling Management School, University of Stirling, FK9 4LA. Email: charles.leleux@stir.ac.uk

C William R Webster is Professor of Public Policy and Management at the University of Stirling. He is a Director of the Centre for Research into Information, Surveillance and Privacy (CRISP), within Stirling Management School, and Chair of the Division of Management, Work and Organisation. His research interests include: everyday surveillance practices, the governance and regulation of surveillance and governing in the information age. He is a recognised expert on Closed Circuit Television (CCTV) in public places. William Webster, Stirling Management School, University of Stirling, FK9 4LA. Email: c.w.r.webster@stir.ac.uk 


\title{
The Sale of Edited Electoral Registers in Scotland: Implications for Privacy, Data Protection and Citizenship
}

\begin{abstract}
This article provides an assessment of the recent phenomenon in Scotland and the United Kingdom of selling edited electoral registers to third parties, and reflects on the implications of this practice for privacy, data protection and citizen-state relations. Drawing on the results of the National Survey of Electoral Registration Officers in Scotland, information is presented on the sale of edited registers, the types of organisation purchasing registers, revenues generated and the number of electors 'opting out' of the edited register. This is the first time such information has been collected nationally and therefore represents a unique Scottish 'snapshot'. The article argues that the sale of edited registers is contentious. The collection of personal information contained within the register is critical for the successful functioning of elections and consequently our representative democratic system, yet the subsequent unrestricted sale of this information for commercial gain potentially undermines trust in democratic processes and alters the informational nature of citizen-state relations. This article offers a first opportunity to reflect on some of the consequences of this practice.
\end{abstract}

\section{Key Words}

Electoral Registration Officers (EROs); National Survey of Scotland's Electoral Registration Officers; electoral registers; citizenship; privacy; data protection 


\section{The Sale of Edited Electoral Registers in Scotland: Implications for Privacy, Data Protection and Citizenship}

\section{Introduction}

Electoral registers play a key role in the functioning of a modern representative democratic system. They contain personal information about individuals and households and ultimately determine who can vote in an election or referendum. They are also used as a means to determine residency and as a key indicator by credit referencing agencies (CRAs) in calculating the credit score of citizens. In the United Kingdom (UK), the creation and use of electoral registers is tightly governed by legal statute and in recent years has included the possibility of selling the register to third parties for financial gain. The sale of electoral registers to third parties has ethical and privacy implications, primarily because of the size and scope of the data contained within the registers, which would include comprehensive geographical coverage and personal information, including: individual names, addresses, household compositions, and in some cases age. There are also potential data protection issues relating to how this information is then used by third parties, with emerging evidence suggesting that the registers are being 'sold on' by purchasers to other parties for unspecified and unregulated purposes. Such practices undermine the core function of the register and raise questions about practices critical to the functioning of a healthy democracy, including the legitimacy of the state to collect and manage large population datasets. It is reasonable to assume that most citizens will understand that their names and addresses need to be on an electoral register to allow them to vote, but one would also suspect that a sizeable proportion are unaware that their personal information in the register is being sold to third parties, or why this happens. Concern has been raised about the lack of awareness of these practices and that the selling of edited registers deters citizens from voting (Big Brother Watch, 2013). Although, there are a range of other deep rooted societal reasons which may explain the trend of declining voter turnout (Russell, 2004).

This article critically assesses the practice of selling electoral registers in Scotland and includes findings from the first National Survey of Electoral Registration Officers (EROs) in Scotland conducted in 2013. The National Survey collected information about the number of edited electoral registers being purchased by third parties, the types of organisation purchasing the registers and estimates of the income generated from the sale of edited registers. Analysis of these findings is placed in the context of the emerging importance of big data, national datasets and the growing awareness of the fundamental need to govern the creation and use of personal information. In addition to the survey, the research also incorporated a desk-based literature review and semi-structured interviews with the Chair of the Scottish Assessors' Association Electoral Registration Committee and two Electoral Registration Officers. The semistructured interviews were used to help design the survey instrument and to explore the validity of the main survey findings.

The article is split into seven main sections. Following the introduction, the second section sets out the role and function of the electoral register, including reference to Electoral Registration Officers (EROs), and describes the distinction between the full 
and edited registers and the origins of the register. The next section places the contemporary use of the electoral register in the context of the historical 'fight' to realise universal suffrage in the UK, the growth of the 'database' state and more recently the practice of 'selling' large state datasets. The fourth section presents the findings of the first National Survey of EROs in Scotland, conducted in 2013, and includes a note about methodology. The subsequent section discusses the survey findings with particular reference to the implications for society and democratic practice, of selling the register. The final section offers concluding comments and identifies issues for policy-makers, regulatory and professional bodies, and governments. Overall, the article makes an important contribution to knowledge, in that, for the first time national data about the use and implications of selling the electoral register is presented and discussed. In doing so, the article draws attention to the risks associated with this practice and possible areas for reform.

\section{The Electoral Register and Electoral Registration Officers}

In Scotland, an Electoral Registration Officer (ERO) is a public official, appointed by a Board comprising of local authority members (or Councillors), whose responsibility it is in terms of the Representation of the People Act 1983 (as amended) to compile annually, a geographically bounded large public dataset, known as 'Register of Electors' which contains the names and addresses of all citizens who are eligible to vote at elections to the UK Parliament, the Scottish Parliament, the European Parliament and to local government bodies, as well as other ad hoc national referendums. The Register of Electors is sometimes referred to as the 'full' or 'closed' register. The ERO also maintains a separate register known as the 'edited' or 'open' register, from which citizens can 'opt out' from having their name included, and which is available for general sale to the public and to organisations and businesses. The UK Electoral Commission (EC), the independent elections watchdog and regulator of political party and election finances, describes the role of the ERO in relation to the two types of registers:

'Registration officers keep two registers - the electoral register and the open register (also known as the edited register). The electoral register lists the names and addresses of everyone who is registered to vote in public elections. The register is used for electoral purposes, such as making sure only eligible people can vote. It is also used for other limited purposes specified in law, such as: detecting crime (e.g. fraud), calling people for jury service, checking credit applications. The open register is an extract of the electoral register, but is not used for elections. It can be bought by any person, company or organisation. For example, it is used by businesses and charities to confirm name and address details. Your name and address will be included in the open register unless you ask for them to be removed. Removing your details from the open register does not affect your right to vote.' (Electoral Commission, 2014).

The compilation of the electoral register is a formal process governed by legal statute. Although it is not an offence for your name not to appear on the electoral register when it is published each March, it is an offence not to provide the information requested on the Voter Registration Form (requiring information about those eligible to vote). Providing false information can lead to a fine of $£ 5,000$ (Representation of the People 
(Scotland) Regulations 2001 reg. 23, and Representation of the People Act 1983 s 13 D). Information requirements on the form include names and nationalities of all persons who can vote at the address, and the names, nationalities and dates of birth of any 16 and 17 year-olds living at the address. The date of birth is printed on the register of an elector who is not yet 18, and EC guidance describes those electors as 'attainers' as they are about to attain the voting age, although exceptionally for the referendum on Scottish independence held in September 2014, the age limit for electors was reduced to 16. Importantly, there is a box on the form headed 'Edited Register' which you are invited to tick 'if you do not want your details to appear on the register which is available for general sale.' Electors were therefore invited to 'opt out' from their details being included in the 'open' register which anyone can buy.

Prior to September 2014, when new arrangements for individual electoral registration were introduced, through the Electoral Registration and Administration Act 2013, the person signing the annual Voter Registration Form, addressed to the head of each household, was responsible for asking each person named on the form if they wished their details included on the edited register, or if they wished to opt out. The Act introduced 'individual electoral registration' in the UK which involved EROs notifying each individual by letter of their current status on the electoral register, i.e. whether or not they were registered to vote and if their name was or was not included on the edited register. The new Act also changed electors' status vis-à-vis the edited register to a permanent one, meaning that they did not have to opt out annually if that was their intention. It is understood from our research with electoral registration officials that the individual notification to electors of their current status regarding the edited register in the autumn of 2014, created a huge surge of requests in Scotland from electors to have their name removed from the edited register, although figures for the increase in take-up of this option are not currently available. The letter to each elector which was issued by the EROs was only sent out after a corroborative cross-check had been carried out with information held by the Department of Work and Pensions and in some cases Council-tax records. This is a good example of public agencies sharing datasets of citizens' information to enhance service provision. Electors' details no longer require to be updated on an annual basis, but each year, from 1 July 2015, every household will be required to confirm whether or not there have been changes to the occupants of the property. The Coalition Government's intentions regarding the introduction of individual electoral registration are summarised in the following extract from the new legislation:

'The Coalition Government has repeatedly stated its commitment to speeding up the implementation of Individual Electoral Registration (IER), in order to tackle electoral fraud, the potential for fraud and the perception of fraud. Doing so will also improve the integrity of our electoral registers and modernise our electoral system, making it more convenient for people to register to vote. We have published an implementation plan that sets out the stages of transition to IER during 2014-2015.' (Electoral Registration and Administration Act 2013)

The electoral register is critical in determining who is eligible to vote in a defined area and therefore core to the functioning of an election and consequently the contemporary representative democratic process. The existence of multiple registers points to possible secondary uses of the register, ones that are arguably less well understood, although the former Annual Voter Registration Form (2013) made clear 
what some of these secondary uses were, including the requirements which were to be undertaken should a citizen wish to 'opt out':

'The full register lists the name and address of everyone who is registered to vote. The Electoral Registration Officer and some local libraries hold a copy. Anyone can look at it, but it is a criminal offence to supply or use copies for purposes other than those set down in law. The main use of the full register is to show who can vote at elections and referendums. Credit reference agencies can use it, but only to check your name and address if you are applying for credit and other purposes specified in law. It can also be used for law enforcement (for further information see: www.aboutmyvote.co.uk)

'The edited register is available for general sale. The edited register can be bought by any person, company or organisation and can be used for commercial activities such as marketing. If you want to opt out of having your details appear on the edited register, please tick the 'Edited Register' column on the form or indicate this preference when using the freephone or internet service. You must also ask each person named on the form if they want to opt out of the edited register. Please note-you need to opt out of the edited register each year, so if you do not want your name to appear on the edited register you will need to indicate this on your form or when using the freephone or internet service - even if you did so last year.' (extract from the Annual Voter Registration Form 2013, Lanarkshire Valuation Joint Board, for the North and South Lanarkshire electoral registration areas)

The edited or open register is a relatively new phenomenon; introduced in Scotland through the Representation of the People (Scotland) (Amendment) Regulations 2002. It came about following the case of Brian Robertson (claimant) versus The City of Wakefield Council and the Secretary of State for the Home Department (defendants), heard on 16 November 2001. This case recorded that on 6 October $2000 \mathrm{Mr}$ Robertson, who objected to his local ERO selling the electoral register to commercial interests, wrote to the ERO in Wakefield stating that he did not intend to complete the annual Voter Registration Form, and referred to the recently introduced Human Rights Act 1998. The court proceedings summarised Mr Robertson's case:

'Claimant's case is that, as a potential elector, he is being unlawfully required to tolerate the dissemination of the Register to commercial interests who utilise it for marketing purposes and that his enfranchisement cannot lawfully be made conditional upon acceptance of this practice.' (R on the application of Robertson v City of Wakefield Metropolitan Council, 2001)

The court found that the 'Claimant has established substantive grounds of challenge' which led to the establishment through legislation of separate full and edited registers. This ruling was predicted to make it harder for CRAs and marketing companies to conduct searches as there would be fewer names published in the edited register (Jay and Davis, 2003).

\section{From the 'Fight' to Secure the 'Right to Vote' in the UK to the Selling of Electoral Registers}


The contemporary practice of selling electoral registers can be placed in the historical context of the struggle to achieve universal suffrage, the emergence of national administrative datasets, the automation and integration of data via eGovernment and more recently the commercialisation of public data. The historical steps leading to universal suffrage, i.e. the right to vote on an equal basis for women and men, was described as a 'franchise issue, [with] the question of who should vote...gradually tidied up by the Reform Acts of 1832, 1867, 1885, 1918 and 1928' (Butler, 2004: 734). What this simple statement does not convey is the sustained struggle to achieve universal suffrage and the contemporary paradox in the ease with which information about voters and their right to vote is 'sold' on a commercial basis. Universal suffrage was established in the UK in 1928 through the Representation of the People (Equal Franchise) Act, which conferred the right to vote to women on the same status as men, that they had to be aged 21 or over and that there was no property ownership requirement in order to vote. The campaign for establishing equal voting status and other forms of political reform was hard fought and took many years to achieve. The suffragette movement held their first meeting in 1869 and used alternative methods of persuasion and protest which continued up until the outbreak of World War I in 1914 (Van Wingerden, 1999; Ramirez et al., 1997). Some campaign groups, notably the Women's Political and Social Union formed in 1903, led by Emmeline and Christabel Pankhurst, engaged in a strategy of civil unrest, which led to some suffragists being imprisoned, where many chose to go on hunger strike (Purvis 1995; Purvis and Wright, 2005; Stanley and Morley, 1988). There is a stark contrast between the lengthy campaign for universal suffrage, which continued for around 60 years (1869-1928), and the relatively recent practice of creating edited registers for general sale, which has happened over a relatively short period of time, and which allows for information about the right to vote to be sold for commercial gain.

The creation of electoral registers in the UK can be placed in the context of the development of large public service datasets and more recently in the automation and sale of these datasets for commercial gain. Historically, the state has created large datasets containing the personal information of citizens for a variety of administrative and democratic purposes, from the administration of tax and benefits, to the creation of standardised service identities, such as passports and driving licences (Webster, 2013). Higgs (2004) describes the historical position on information gathering in England by the state from the Middle Ages, and details the surprisingly extensive array of datasets relating to identifiable individuals, already containing more than one million records, held by UK Government departments in 1978 prior to innovations in eGovernment. These large datasets have become critical to the functioning of modern administrative systems, especially for the delivery of universal and equitable public services (Taylor and Webster, 1996). Over time, and with the development of new information and communication technologies, processes that were initially 'paperbased' have become automated, more sophisticated, with alternative uses being identified and exploited. 'Data-sharing' has become a key enabler for public service reform and enhanced service performance, and is enshrined in data protection and processing guidelines (Webster, 2013). In this respect, the state has always created and used data, including personal data about citizens, for a range of public service and democratic practices, including national security and taxation: 'it has become normal for public agencies and other organisations to create and maintain large databases of records containing personal information and for administrators with 
administrative expertise to maintain and service these records' (Webster, 2012: 258). Alongside the exploitation of these datasets for service improvements, including the cross-referencing of information between datasets, they are increasingly being exploited for financial gain.

Current interest in 'Big Data' or 'Data Science' demonstrates a desire to mine existing data for the benefit of society and for financial gain. This is not a new phenomenon; state datasets have been utilised for commercial gain for a number of years. For example, the Driver and Vehicle Licensing Agency (DVLA) has for many years charged commercial operators who wish to check the ownership of vehicles using their premises, and such practices are common at supermarkets and garage forecourts (Royal Automobile Club, 2013). Here the drive is to maximise any financial value embedded in the creation and existence of the dataset. Electoral registers have not been immune from this trend and have also been increasingly used for alternative uses, that is unrelated to elections. They are used by CRAs and other financial institutions to verify the existence of individual citizens and to help profile their creditworthiness. They play a significant role in securing mortgages and in determining property ownership. It could be argued that the secondary role of electoral registers is in our modern capitalist system more important than their primary function. Currently in the United States of America, there is a practice of using electoral registers to identify individuals, particularly young electors, for targeted political campaigning and canvassing through various forms of social media, including inducements (Bennett, 2013). Bennett goes on to note that 'the main political parties in the UK have also operated such databases (voter management software)... using similar proprietary software to their counterparts in the United States. They too augment the basic address information from the electoral roll with additional personal data on supporters and non-supporters alike.' (Bennett, 2014: 5). Whilst it is clear that the Electoral Register is increasingly used for a variety of purposes and that there is a desire to generate commercial value from public datasets, relatively little is known about the revenue generated from sales of the register or who is purchasing the register and why.

\section{The First National Survey of Electoral Registration Officers in Scotland}

The first national survey of EROs in Scotland was conducted in 2013 by the University of Stirling with a view to identifying the extent to which electoral registers are sold, to whom and for what purposes. The survey was administered online, using the 'SurveyMonkey' application, and was sent to all 33 Electoral Registration Office areas in Scotland. The survey was issued on 26 September 2013, with reminders issued on 25 October and 8 November, and closed on 14 November 2013. All EROs were assured that the survey results would be anonymised and that neither their names nor their electoral registration office areas would be identifiable in the survey results.

Responses, either full or in part, were received from twenty-three out of the thirty-three Electoral Registration Office areas, resulting in an overall response rate of $69.7 \%$. Full responses (all questions answered) were received from seven respondents, and partial responses (one or more questions unanswered) from sixteen, with the most common reason being given for partial returns, as: 'our document retention policy 
precludes keeping this information for so long'. Most EROs did not keep formal records on the sale of registers from 2003 due to their data retention schedules (internally agreed rules regarding how long documents and data will be stored) and consequently some responses contained partial information for the period requested. EROs are not named in the Freedom of Information (Scotland) Act 2002 and were therefore not obliged by law to disclose their records or to provide any information in connection with the survey. In this respect, participation in the survey was entirely voluntary and relied on the goodwill of the respondents. For those reasons, the authors varied the date ranges of different information requested to attempt to achieve as high a response rate as possible. There are no identifiable patterns emerging from the responses which would indicate that predominantly urban or predominantly rural areas were more or less likely to participate. The survey collected information in five main areas, listed below, with the findings from each presented in the next section of the article. The subsections of the survey collected information about:

- where the general public had access to full electoral registers free of charge,

- the number of full and edited electoral registers sold between 2003 and 2012,

- the 'type' of organisations which have been making these purchases,

- the estimated percentage of electors who have chosen to have their name removed from the edited electoral registers for the period 2010-2012, and

- the estimated total income generated from the sale of edited and full registers for the period 2010-2012.

\section{Accessing Full Electoral Registers by the General Public Free of Charge}

The EROs who participated in the survey ( 23 areas) all provided information about where in their electoral registration area members of the public could access full electoral registers free of charge. The main points to note are:

- all twenty-three EROs advised that members of the public could access the full electoral register within a public library (usually the central or main library),

- all twenty-three EROs advised that members of the public could access the full electoral register at the offices of the ERO,

- eight EROs reported that full registers could be accessed by contacting the Returning Officer at a local government office,

- three EROs reported that electors can telephone or write to them for confirmation of registration, and

- three EROs reported that members of the public may access the full electoral register at local or rural post offices.

\section{Number of Edited Registers Sold Between 2003 and 2012}

Full information was supplied from seven areas about the number of edited registers sold between 2003 and 2012, while eleven provided partially completed responses, due primarily to their document retention schedules, and five did not supply any information. Respondents were asked to indicate the number of edited registers that 
they had sold to various organisations, as well as the actual numbers of full registers sold to CRAs. Full details of the responses are provided in Table I. The main points to note are:

- ten of the thirty-three EROs in Scotland (30.3\%) provided actual numbers of full registers sold to CRAs, during the period 2003-2012, and these were all within the range of three to five for any given year. It is probably safe to assume that the same CRAs are purchasing the full registers on a widespread basis across Scotland,

- between one and five debt collection companies were involved in purchasing edited registers from four Electoral Registration areas,

- between one and five marketing companies were involved in purchasing edited registers from ten Electoral Registration areas,

- in twelve electoral registration areas, it was reported that one to five private individuals purchased the edited register or sections of it, and

- in fourteen Electoral Registration areas, 'other' organisations, as described in more detail in Table I, purchased edited registers. The types of organisations involved in this practice included: church groups, charities, community councils, housing associations, educational establishments, property companies, mailing companies, double glazing companies, transport groups, environmental agencies and other miscellaneous groups.

\section{Insert Table I here.}

\section{Estimated Percentage of Electors Who Have Chosen to Have Their Name Removed From the Edited Registers between 2010 and 2012}

Data was supplied from seventeen Electoral Registration Office areas relating to the section of the survey seeking to establish how many citizens, as a proportion of the electorate, had chosen not to be included in Edited Register. This was for the period 2010-2012. Full details of the responses are provided in Table II. The main points to note are:

- the highest single percentage recorded for any one particular year was $41 \%$ (Respondent Nos. 12 (2010) and 20 (2012),

- the lowest single percentage recorded for any one particular year was $9 \%$ (Respondent No. 18, 2011 and 2012),

- the mean (average) percentage for 2010 was $29 \%$, for 2011 it was $26 \%$ and for $201227 \%$, and

- $\quad$ for the three-year period 2010-2012 the mean (average) percentage was 27\%; the median (middle) percentage was $30 \%$, and the mode (most common) was $30 \%$ (six entries).

\section{Insert Table II here.}

From the results of this part of the survey it can be concluded that there is no identifiable pattern emerging which could be used to demonstrate either increasing or 
decreasing elector preference for having their name removed from the register available for general sale.

\section{Estimated Income Generated from the Sale of Edited Registers}

Data was supplied from seventeen areas relating to the levels of income generated from the sale of Edited Registers, for the period 2010-2012. There is no standard charge for supplying extracts or full copies of the edited register, as this varies depending upon the volume of data requested, across Valuation Joint Boards, and local authorities (where they have responsibility for electoral registration matters). Full details of the responses are provided in Table III. The main points are:

- of the twelve EROs who provided full information for years 2010-2012, six of these experienced a year-on-year reduction in income generated, while only one ERO experienced a year on year increase in income generated. Of the remainder, due to incomplete information, no conclusion could be drawn as to whether or not their income had declined or increased,

- the highest single amount of income generated for any one particular year was $£ 2,968$ (Respondent No. 19, 2011),

- the lowest single amount of income generated for any one particular year was $£ 18$ (Respondent No. 3, 2012),

- the mean (average) amount of income generated by each ERO for the three year period was £656, the median (middle) amount of income generated for the three year period was $£ 462$, and the mode (most common range of income generated) was $£ 1,000-£ 1,999$,

- the total amount of income generated for 2010 was: £9,394, for $2011 £ 9,744$, and for $2012 £ 9,069$, and

- the total combined income generated for 2010-2012 was £28,207.

\section{Insert Table III here.}

Clearly, the income generated from the sale of edited electoral registers is relatively insignificant. No particular patterns are evident in terms of income growth or decline and the income figures mirror the fairly static position with regard to the total number of sales for the longer period of 2003-2012. However, it would be dangerous to conclude that the relatively low income figures have little significance for data protection, privacy and citizen-state relations, as the wider impact of the sale of edited registers may be much greater than the relatively low figures imply, due to the practice of 'selling-on' of the registers to other organisations and third parties. The practice of 'selling-on' undermines income generated by the EROs and makes it impossible to see who is buying and using the datasets. The selling-on of electoral registers was mentioned by EROs in the semi-structured interviews and described as 'common practice'. Typically, a licenced CRA would legitimately purchase a copy of the full electoral register only to amend it and sell it on to third parties: 'it is our understanding that some of the said CRAs strip from the register those electors who have opted out of the edited register and subsequently sell the data relating to those electors on the edited electoral register onto third parties' (ERO, anonymous, 2013). 


\section{Survey Findings: Overview}

The National Survey of EROs in Scotland conducted in 2013 provides, for the first time, data on the current practice by EROs of selling edited electoral registers to third parties. We now know from the results of the survey and from the semi-structured interviews: (1) the outlets from where members of the public can access the full register free of charge, primarily offices of the ERO and public libraries, and occasionally local government offices and post offices; (2) the degree to which full registers are purchased by CRAs, with no ERO selling to more than five CRAs in any one year; (3) that the scale of selling edited registers to other organisations and private individuals is also low, however the breadth of organisations involved is extensive, ranging from assorted commercial interests, to public bodies, church groups and private individuals, with emerging evidence that further 'selling-on' of both edited and full registers is believed to be commonplace; (4) that the number of citizens choosing annually to 'opt out' of having their personal details included on the edited register, is fairly substantial, at around $27 \%$, with no particular trend either upward or downward emerging; and (5) that the sale of registers is a very small income stream for EROs, generating around $£ 656$ per electoral registration area, with the Scotland-wide average annual total figure for 2010-2012 being just over £9,400.

\section{Policy Discourse on the Use of Edited Registers}

The subject of the sale of electoral registers has entered policy-making discourse in the UK, with the principal actors being the Electoral Commission, the UK Parliament, the UK Information Commissioner, the Association of Electoral Administrators, CRAs and debt collection companies. Notably, the 'voice' of citizens appears to be largely absent. One central area of concern relating to the existence of edited registers was the annual requirement to 'opt out'. Here, the issue was that electors had to periodically remember to choose not to be included and that inclusion in the edited register was not necessarily a matter of conscious choice. The (UK) Electoral Commission has expressed the view that there should be an automatic position of 'opt out' which would then require electors to decide to 'opt in' to the 'edited' register if they were happy for their personal details to be sold to third parties (Electoral Commission, 2010). Calls for the sale of edited registers to be abolished have been raised by various actors, including the Political and Constitutional Reform Select Committee of the House of Commons, the Electoral Commission and the Association of Electoral Administrators (House of Commons Library Notes, 2012, 2014). The UK Information Commissioner (ICO) expressed the view prior to the introduction of full and edited registers in 2002, that 'the sale of the electoral roll was inconsistent with the requirements of the Data Protection Act 1998 and Human Rights Act 1998' (ICO, 2011: 24). The ICO then called for the abolition of sales of the edited register, due to this being 'an unsatisfactory way for local authorities to treat personal information' (Data Sharing Review, 2008: 73). The ICO has also issued advice on the illegal sale of citizens' private details: the Information Commissioner recommends that all relevant regulatory and professional bodies should take a strong line to tackle any involvement in the illegal trade in personal information' (ICO, 2006: 33). Contrastingly support for the retention of the practice has been voiced by marketing companies, CRAs and debt collection companies. Although the Data Sharing Review (2008) included a recommendation for the Government to abolish the edited register, (House of Commons Library Note, 
2008), the Coalition Government's position was that the edited register would be retained (House of Commons Library Notes, 2012 and 2014).

Rubin (2010) notes that consultation conducted by the Ministry of Justice on the future of the electoral roll raises concern about the wording on electoral registration literature, such as the Voter Information Form, because it does not inform the public adequately about the existence and function of the edited register or how they can 'opt out'. Existing wording on the Voter Information Form 'creates a risk that people are not sufficiently aware that data provided on electoral registration forms could be sold or that they have a choice about whether they are included on the Edited Register. A further risk is that people do not realize that they have been entered in the Edited Register because they missed their opportunity to 'opt out'. (Rubin, 2010: 341). Inadequacies in the information available for electors about the edited register may explain, in part, why the number of electors choosing to 'opt out' of the edited register is around $27 \%$. This includes the possible lack of awareness or indifference to the requirement contained in the former Annual Voter Registration Form, for the head of the household to ask all electors resident in the household if they wished to opt out of the edited register. The Electoral Commission conducted an annual winter 'tracker' survey of around 1,200 UK residents in 2013 on a wide range of electoral issues, and asked citizens about their awareness of the practice of selling the registers, and whether or not removal of availability to opt out would influence their decision to register: $3 \%$ said it would make them more likely; $54 \%$ said less likely, $41 \%$ said it would make no difference, and $2 \%$ said 'don't know'. Approximately $47 \%$ of interviewees knew that they could choose whether or not to have their information included on the register which is available for sale (Electoral Commission, 2013).

The practice of selling edited registers is mirrored in other service domains where large state databases of citizens' information have been utilised for purposes other than those for which they were created. For example, the inclusion of UK postcode data in the privatisation and sale of Royal Mail has been controversial as it is a universal dataset linking citizens to property and locations, and has consequently been criticised by the House of Commons Public Administration Committee (The Guardian Online, 2014). The UK Drivers and Vehicle Licensing Agency (DVLA) has for many years sold driver's information relating to car ownership to third parties for commercial gain, with this practice becoming a core revenue stream. It was noted that the DVLA made $£ 10.4$ million from selling drivers' details, an increase of up to $£ 8$ million on previous years. The agency sold the details at a rate of around 50,000 a week, totalling 2.4 million in a year. Details are sold to approved companies that give out parking fines and clamp cars. Some of the companies the DVLA has allowed to buy details have been criticised for using heavy handed tactics with drivers to ensure fines are paid'. (Royal Automobile Club, 2013). These examples demonstrate a desire to create commercial value from public datasets and via the reuse of personal information. Data sharing between public services is a key element of eGovernment and current initiatives in 'Big Data' point to the further exploitation of public and personal data. The degree to which citizens have any control over how 'their' data is used in these initiatives is yet to be determined, despite the processing of personal data being carefully regulated by the Data Protection Act 1998.

\section{Concluding Discussion}


It is evident, with the development of bureaucracies and new ICTs, that there has been considerable growth in the number and types of large databases in modern society. The emergence of these databases has been central to the delivery of contemporary public services and democratic practices. Alongside the creation of these datasets have been new opportunities to use data for alternative purposes and to combine and transform data in hitherto unforeseen ways. Such developments have occurred alongside a growing recognition of the 'value' of personal information and regulatory requirement to process personal information in accordance with data processing principles and laws. These developments have created tension between existing institutional processes and between citizens and the state, especially in regard to the sale of citizens' personal information for commercial gain. The UK Electoral Register has not been immune from these developments and in recent years an edited register has been created and sold to third parties for commercial gain. This practice is contested and has generated debate amongst politicians, policy-makers, regulatory bodies and professional organisations, with the UK Government deciding in 2012 to maintain the status quo in allowing sales to continue. Further conflict in the sale of edited electoral registers is to be found in relation to compatibility of the practice with the objectives of the Human Rights Act 1998 and the European Convention on Human Rights. It can be argued that personal privacy has been compromised by the sale of citizens' information, especially where citizens have little or no control over this process. This has serious implications for vulnerable persons who do not have the capacity to have their name removed from the edited register, and for those who simply wish to have the right to remain anonymous, for example those who were formerly in an abusive relationship, and who do not want any future contact with a former partner.

Concern has been raised about the lack of public awareness of the sale of edited registers, that the practice was deterring some electors from voting, and that this was producing undesirable democratic consequences (Big Brother Watch, 2013). In their 2013 report, Big Brother Watch reported on the sales of registers over a six year period: 2007-12, and although the headline figure at first glance is high at £265,161, this is for 307 Councils which averages out at $£ 863$ per Council, compared to an average of $£ 656$ per electoral registration office area in Scotland for the 3 year period of the National Survey (2010-12). Big Brother Watch (2013) had written to Scotland's 32 local authorities inviting them to participate in the survey, however there is only a very small number of local authorities who are responsible for electoral registration matters in Scotland, with the remaining areas being the responsibility of the ERO. The result was that only 6 local authorities returned information (out of thirty-three Electoral Registration Office areas).

There is very little published work on the sale of edited electoral registers and the research presented in this article contributes new knowledge in the area. The National Survey of EROs in Scotland provides a unique insight into how edited registers in Scotland are sold and used. It is the first time a national picture relating to the sale of registers has been possible. The survey highlighted that the frequency of sales and the incomes generated were relatively low, although there is a wide range of organisations involved in this practice, including commercial companies, community groups and private individuals. The survey also highlighted the number of electors who are annually choosing to 'opt out' of having their name included in the register for general sale, at approximately $27 \%$, of the electorate, although this figure is estimated 
to rise substantially as elector awareness increases of the practice of selling-on of personal details, following the introduction of individual electoral registration. There is also evidence of the selling-on of electoral registers by some third parties to other parties, although very little is known about the extent of this controversial and illegal practice.

Whilst the research presented in this article offers a first opportunity to set out the scale of the sale of edited registers in Scotland, it has highlighted important areas for further research. In particular, it would be useful to have a better understanding of the awareness, opinions and attitudes of the public to the selling of their personal information contained in the electoral registers, and whether or not this has an impact on citizens' propensity to vote. It would also be of interest to explore whether or not there are parallels in practice with other parts of the UK, to map changes in sales over time, and to find out more about how registers purchased by third parties are actually used. Information is available from Wales from the Western Mail newspaper, which published the results of a survey of Welsh local authorities undertaken in 2012 of the income generated from sales of registers over the preceding four year period. The figures were obtained through Freedom Of Information legislation (which Scotland's EROs are not bound by), revealed that $£ 143,689$ had been generated from sales within fourteen of Wales' twenty two local authorities. Five Councils had not responded and three advised that they were unable to release the information. Commenting on the Welsh findings, Eric King, head of research at Privacy International, said:

'While it is possible to opt out from having the data you hand over to public bodies used for commercial purposes, most people aren't really aware of this as an option so by default their information is sold without their consent or knowledge. People have the right to know who has access to their data and what is being done with it. We need greater transparency and a clearer notification process to ensure people stay in control of their personal information' (King, 2012).

Income generated from sales of registers in Wales shows an annual average of approximately $£ 36,000$ compared to around $£ 9,400$ for Scotland. The Welsh results are significantly higher than those from Scotland (National Survey of EROs, 2013) and for the UK as a whole (Big Brother Watch, 2013). The national variations of income generated from sales is not thought to be related to varying survey response levels by Electoral Registration Officers or local authorities. The reasons why the Welsh income levels are higher than Scotland or for the UK as a whole require further investigation.

The subject of the sale of electoral registers has now entered the policy-making arena in the UK, with calls for the sale of Edited Registers to be abolished having been raised by various actors, including the Electoral Commission, the Political and Constitutional Reform Committee of the UK Parliament, the Association of Electoral Administrators, and as a recommendation of The Data Sharing Review (2008). In 2012, the Coalition Government's position was that there were no plans to abolish the edited register. However, related to this, on 2 October 2014, the Scottish Government announced plans to introduce legislation to stop local authorities from pursuing people for historic Council Tax debts, with First Minister Alex Salmond announcing: 
This issue also highlights the need to seek the power from Westminster to control the electoral register, specifically to remove the ability of the register to be sold to private debt collectors. (Salmond, 2014)

With the changes in individual electoral registration introduced with the Electoral Registration and Administration Act 2013 and the consequent surge in requests from electors to have their names removed from the edited register, this is likely to lead to increasing pressure for a change of process, and perhaps legislation, so that there is to be an automatic position of 'opt out' which would then require electors to actively choose to 'opt in' to the Edited Register for those who were happy for their personal details to be sold to third parties. This will undermine the commercial value of the dataset and will give citizens a small but increasing degree of control over how their personal data is used. Only 'time will tell' if this will lead to a reduction in the sale of edited registers.

\section{Acknowledgements}

The authors gratefully acknowledge the Electoral Registration Officers (EROs) who participated in the National Survey of EROs in Scotland, 2013; the Chair of the Scottish Assessors' Association Electoral Registration Committee for advice about the compilation of the survey, and Fiona Millar (University of Stirling) for administering the survey.

\section{References}

Bennett, C. J. (2013). First Annual CRISP Lecture, 'The Politics of Privacy and the Privacy of Politics', University of Edinburgh.

Bennett, C. J. (2014). Knowing How You Vote before you Do: Micro-targeting, Voter Surveillance and Democracy. Surveillance Studies Network (SSN) Conference, Barcelona, Spain, 26 April 2014.

Big Brother Watch (2013). Democratic value: Exposing the scale of the commercial sale of the edited electoral roll, A Big Brother Watch report.

Butler, D. (2004). Electoral reform. Parliamentary Affairs, Hansard Society, 57, 4, 734-743.

Data Protection Act (1998).

Data Sharing Review (2008). Walport, M. and Thomas, R. Ministry of Justice, July 2008; 8.89, 19, p.73.

http://webarchive.nationalarchives.gov.uk/+/http://www.justice.gov.uk/docs/datasharing-review.pdf

Electoral Commission (2010). Response to the consultation paper: Electoral registers: proposed changes to the edited register.

Electoral Commission (2013). Winter Tracker Survey: http://www.electoralcommission.org.uk/_data/assets/pdf_file/0003/165855/Winter -tracker-2013-topline-results-WEB.pdf

Electoral Commission (2014). 'What is the electoral register?' http://www.electoralcommission.org.uk/faq/voting-and-registration/what-is-theelectoral-register

Electoral Registration and Administration Act (2013). 
Electoral Registration Officer (2013) (anonymised email correspondence, 14.10.13).

European Convention on Human Rights (1950). European Court of Human Rights, Council of Europe, Strasbourg,

Freedom of Information (Scotland) Act (2002).

Higgs, E. (2004). The Information State in England: The Central Collection of Information on Citizens since 1500: Palgrave Macmillan, Basingstoke.

House of Commons Library (2008). Standard Note: SN/PC/01020.

House of Commons Library (2012). Standard Note: SN/PC/06198.

House of Commons Library (2014). Standard Note: SN/PC/01020

Human Rights Act (1998).

Information Commissioner's Office (2006). What Price Privacy? The unlawful trade in confidential personal information. Report to Parliament, 10.05.2006.

Information Commissioner's Office (2011). 'Making the data protection register available in a machine readable and reusable format'. Report, p.24.

Jay, R. and Davies, A. (2008). High Court Ruling Puts Credit Industry at Risk, Credit Management, ProQuest, ABI/INFORM.

King, E. (2012) 'Welsh Councils Make £143,000 from Electoral Roll Data'. The Western Mail, 10.09.2012. http://www.walesonline.co.uk/news/wales-news/welshcouncils-make-143000-electoral-2023782.

Lanarkshire Valuation Joint Board (2013). Annual Voter Registration Form.

Purvis, J, (1995). The prison experiences of the suffragettes in Edwardian Britain, Women's History Review, 4, 1, 103-133: Taylor \& Francis.

Purvis, J. and Wright, M. (2005). Writing Suffragette History: the contending autobiographical narratives of the Pankhursts, Women's History Review, 14, 3-4, 405-433, Taylor \& Francis.

$\mathrm{R}$ (on the application of Robertson) v City of Wakefield Metropolitan Council (2001). EWHC Admin 915. http://www.bailii.org/ew/cases/EWHC/Admin/2001/915.html.

Ramirez, F. O., Soysal, Y. and Shanahan, S. (1997). The changing logic of political citizenship: Cross-national acquisition of women's suffrage rights, 1890 to 1990, American Sociological Review, Vol. 62, No.5.

Representation of the People (Equal Franchise) Act (1928).

Representation of the People (Scotland) Regulations (2001), Reg. 23.

Representation of the People Act (1983), S.13D.

Representation of the People (Scotland) (Amendment) Regulations (2002).

Royal Automobile Club (2013). DVLA makes millions from selling drivers' details. 18 April 2014. http://www.rac.co.uk/forum/showthread.php?17564-DVLA-makemillions-from-selling-drivers-details.

Rubin, L. (2010). Ministry of Justice consults on the future of the electoral roll, Journal of Direct, Data and Digital Marketing Practice, 11, 4, 341-342: Nature Publishing Group.

Russell, A. (2004). The truth about youth? Media portrayals of young people and politics in Britain, Journal of Public Affairs, 4, 4, 347-354: Wiley Online Library.

Salmond, A. (2014). 'Poll Tax arrears collection to be scrapped' Scottish Government Website, 04.10.2014:

http://www.wired-

gov.net/wg/news.nsf/articles/Poll+Tax+arrears+collection+to+be+scrapped+04102 014090507?open

Stanley, L. and Morley, A. (1988). The Life and Death of Emily Wilding Davison: A Biographical Detective Story: Women's Press. 
Taylor, J. A., \& Webster, C. W. R. (1996). Universalism: public services and citizenship in the information age. Information Infrastructure and Policy, 5, 217233.

The Guardian Online (2014). Royal Mail privatisation: ministers rebuked for selling postcode data. 17 March 2014. http://www.theguardian.com/uknews/2014/mar/17/royal-mail-privatisation-ministers-rebuked-selling-data.

University of Stirling (2013). National Survey of Electoral Registration Officers in Scotland, 2013.

Van Wingerden, S. A. (1999). The women's suffrage movement in Britain, 18661928: Palgrave Macmillan.

Webster, C. William R., (2012). Surveillance as X-ray. Information Polity, 17, 3/4, 251-265.

Webster, C. William R.,(2013). "Public Administration as Surveillance", in Ball, Kirstie, Haggerty, Kevin D. and Lyon, David (eds.), Routledge Handbook of Surveillance Studies, London, 2012, 313-320. 
Table I - How many edited or full registers were sold to the following types of organisations (to the nearest five), each year for the period 2003-2012*:

\begin{tabular}{|c|c|c|c|c|c|}
\hline $\begin{array}{c}\text { Respondent } \\
\text { Number }\end{array}$ & $\begin{array}{c}\text { Credit } \\
\text { Reference }\end{array}$ & $\begin{array}{c}\text { Debt } \\
\text { Collection }\end{array}$ & Marketing & $\begin{array}{c}\text { Private } \\
\text { Individuals }\end{array}$ & $\begin{array}{c}\text { Other } \\
\text { Organisations }^{\star \star}\end{array}$ \\
\hline 1 & - & - & - & - & - \\
\hline 2 & - & - & $1-5 \times 1$ year & $\begin{array}{l}1-5 \times 8 \text { years } \\
6-10 \times 2 \text { years }\end{array}$ & $\begin{array}{l}\text { Educational } \times 1 \\
\text { Companies } \times 2 \\
\text { Community } \times 1\end{array}$ \\
\hline 3 & $1-5 \times 6$ years & $1-5 \times 1$ year & $1-5 \times 3$ years & $1-5 \times 3$ years & \\
\hline 4 & $1-5 \times 1$ year & - & - & - & - \\
\hline 5 & - & - & - & - & - \\
\hline 6 & - & - & - & - & - \\
\hline 7 & $1-5 \times 6$ years & - & $1-5 \times 4$ years & - & $\begin{array}{l}\text { Mailing } \times 1 \\
\text { Property } \times 1\end{array}$ \\
\hline 8 & $1-5 \times 6$ years & $1-5 \times 1$ year & $1-5 \times 2$ years & $1-5 \times 1$ year & - \\
\hline 9 & - & - & - & $1-5 \times 3$ years & - \\
\hline 10 & - & - & - & - & - \\
\hline 11 & $1-5 \times 10$ years & - & - & - & Police $\times 2$ \\
\hline 12 & - & - & - & $1-5 \times 6$ years & $\begin{array}{c}\text { Care/charity } \times 5 \\
\text { Mailing } \times 3 \\
\text { Property x } 4 \\
\text { Financial } \times 4 \\
\text { Miscellaneous } \\
\text { (jeweller, housing, } \\
\text { energy etc. } \times 10 \text { ) }\end{array}$ \\
\hline 13 & - & - & $1-5 \times 5$ years & - & $\begin{array}{l}\text { Public authority } \times 2 \\
\text { Religious } \times 1\end{array}$ \\
\hline 14 & - & - & $1-5 \times 5$ years & - & $\begin{array}{c}\text { Public authority } \times 3 \\
\text { Religious } \times 1 \\
\text { Housing } \times 1\end{array}$ \\
\hline 15 & $1-5 \times 6$ years & - & - & $1-5 \times 2$ years & $\begin{array}{c}\text { Energy } \times 4 \\
\text { Church } \times 4 \\
\text { Environmental } \times 3\end{array}$ \\
\hline 16 & $1-5 \times 6$ years & $1-5 \times 5$ years & $1-5 \times 1$ year & $1-5 \times 2$ years & $\begin{array}{c}\text { Energy } \times 5 \\
\text { Church } \times 5 \\
\text { Environmental x } 1 \\
\text { Mailing } \times 1 \\
\text { Insurance } \times 1\end{array}$ \\
\hline 17 & $1-5 \times 6$ years & - & $1-5 \times 2$ years & $1-5 \times 3$ years & $\begin{array}{c}\text { Energy } \times 3 \\
\text { Church } \times 4 \\
\text { Environmental } \times 2 \\
\text { Mailing } \times 1 \\
\text { Insurance } \times 1 \\
\text { Double glazing } \times 2\end{array}$ \\
\hline 18 & - & - & - & - & $\begin{array}{c}\text { Church x } 9 \\
\text { Community x } 9\end{array}$ \\
\hline 19 & $1-5 \times 6$ years & $1-5 \times 1$ year & $\begin{array}{l}1-5 \times 4 \text { years } \\
6-10 \times 2 \text { years }\end{array}$ & $\begin{array}{c}1-5 \times 4 \text { years } \\
6-10 \times 2 \text { years }\end{array}$ & $\begin{array}{c}\text { Local councils } \times 10 \\
\text { Medical } \times 1 \\
\text { Courts } \times 2 \\
\text { Housing } \times 3 \\
\text { Community } \times 9 \\
\text { Benefits } \times 1 \\
\text { Educational } \times 2 \\
\text { Harbour master } \times 1 \\
\text { Miscellaneous } 104\end{array}$ \\
\hline 20 & - & - & $1-5 \times 10$ years & $1-5 \times 10$ years & $\begin{array}{c}\text { Police } \times 1 \\
\text { Local council x } 1\end{array}$ \\
\hline
\end{tabular}




\begin{tabular}{|c|c|c|c|c|c|}
\hline 21 & & & & & Community council $\times 1$ \\
\hline 22 & $1-5 \times 10$ years & - & - & - & - \\
\hline 23 & $1-5 \times 9$ years & - & - & $1-5 \times 6$ years & $\begin{array}{c}\text { Council depts } \times 4 \\
\text { Ferry company } \times 4 \\
\text { Educational } \times 2 \text { Local } \\
\text { businesses } \times 8 \\
\text { Other public bodies } \times 2 \\
\text { Voluntary groups } \times 2 \\
\text { Miscellaneous } \times 3\end{array}$ \\
\hline TOTALS & 11 entries & 4 entries & 10 entries & $1-5 \times 5$ years & $\begin{array}{c}\text { Local councils } \times 8 \\
\text { Educational } \times 4 \\
\text { Transport } \times 3 \\
\text { Consultants } \times 4 \\
\text { Mailing } \times 1 \\
\text { 12 entries } \\
\text { Miscellaneous } \times 3\end{array}$ \\
\hline
\end{tabular}

*where answers were provided, they related mostly to the years 2007-2012, as many EROs have not kept records prior to that period due to their document retention schedules.

${ }^{* *}$ expressed as number of entries over the survey period, 2003-2012. 
Table II - Estimated percentage of electors who have chosen to have their name removed from the edited registers: 2010-12

\begin{tabular}{|c|c|c|c|}
\hline Respondent Number & 2010 (\%) & $2011(\%)$ & 2012 (\%) \\
\hline 1 & - & - & - \\
\hline 2 & 16 & 17 & 18 \\
\hline 3 & - & 30 & 34 \\
\hline 4 & - & - & - \\
\hline 5 & - & - & - \\
\hline 6 & - & - & - \\
\hline 7 & - & 30 & 34 \\
\hline 8 & - & 30 & 34 \\
\hline 9 & 34 & 26 & 33 \\
\hline 10 & - & - & - \\
\hline $11^{*}$ & $(8,426)$ & $(8,764)$ & $(9,990)$ \\
\hline 12 & 41 & 37 & 36 \\
\hline 13 & 35 & 21 & 23 \\
\hline 14 & 33 & 21 & 22 \\
\hline 15 & 30 & 27 & 27 \\
\hline 16 & 34 & 30 & 30 \\
\hline 17 & 35 & 32 & 31 \\
\hline 18 & 11 & 9 & 9 \\
\hline 19 & - & 21 & 20 \\
\hline 20 & 32 & 38 & 41 \\
\hline 21 & - & - & - \\
\hline 22 & 23 & 21 & 20 \\
\hline 23 & 22 & 21 & 19 \\
\hline Averages & 29 & 26 & 27 \\
\hline
\end{tabular}

* Respondent No.11 provided actual numbers of electors, as opposed to percentages 
Table III - Income Generated from Sales of Edited Registers ( $($ )

\begin{tabular}{|c|c|c|c|}
\hline Respondent Number & $\mathbf{2 0 1 0}$ & $\mathbf{2 0 1 1}$ & $\mathbf{2 0 1 2}$ \\
\hline 1 & - & - & - \\
\hline 2 & 503 & 100 & 78 \\
\hline 3 & 300 & 100 & - \\
\hline 4 & - & - & - \\
\hline 5 & - & - & - \\
\hline 6 & - & 49 & - \\
\hline 7 & 100 & - & 56 \\
\hline 8 & 29 & - & - \\
\hline 9 & - & - & 205 \\
\hline 10 & - & 32 & 397 \\
\hline 11 & - & 452 & 358 \\
\hline 12 & 429 & 57 & 1,076 \\
\hline 13 & 775 & 61 & 1,107 \\
\hline 14 & 581 & 1,294 & 1,080 \\
\hline 15 & 1,386 & 1,252 & 155 \\
\hline 16 & 1,494 & 1,213 & 2,702 \\
\hline 18 & 1,278 & 645 & - \\
\hline 19 & 933 & 2,968 & 1,169 \\
\hline 20 & - & 344 & 208 \\
\hline 21 & 300 & - & 9,071 \\
\hline 22 & - & 1,098 & 82 \\
\hline 23 & 1,139 & 9,747 & \\
\hline TOTALS & 149 & & - \\
\hline & 9,396 & & \\
\hline
\end{tabular}

